\title{
Occupational risk factors for renal cell carcinoma: a case-control study
}

\author{
Anne Aupérin, Simone Benhamou, Catherine Ory-Paoletti, Robert Flamant
}

\begin{abstract}
A case-control study of 196 histologically proved cases of renal cell carcinoma and 347 controls matched for age at interview, sex, hospital, and interviewer was conducted in France between 1987 and 1991. A complete occupational history was recorded for each patient and occupations were coded blindly according to the International Standard Classification of Occupations. In women, none of the risks were significant. Among men, after adjustment for the educational level, cigarette smoking, and Quetelet index before diagnosis, significantly increased matched odds ratios (ORs) were found for sales workers $(O R=2 \cdot 1,95 \%$ confidence interval $(95 \%$ CI) $1 \cdot 2-4 \cdot 0)$, managers $(O R=3 \cdot 3,95 \%$ CI $1 \cdot 2-8 \cdot 9)$, and textile workers and tailors $(O R=6 \cdot 2$, 95\% CI 1-1-33.7). For this last occupational group, an increase in risk was found with an increased duration of exposure.
\end{abstract}

(Occup Environ Med 1994;57:426-428)

Cancers of the urinary tract were the subject of a recent descriptive epidemiological study. ${ }^{1}$ These cancers account for $7 \%$ of all those diagnosed. The most common site within the urinary tract among white patients in the United States is the bladder $(69 \%)$. Cancers of the renal parenchyma (23\%), the renal pelvis $(5 \%)$, the ureter $(3 \%)$, and the urethra (1\%) occur less often.

Little is known about the aetiology of renal cell carcinoma, but tobacco smoking and obesity seem to be the most consistently reported risk factors. The occupational determinants of renal cancer are poorly understood, but the fact that several agents have a carcinogenic effect on the kidney in laboratory animals suggests that cancer of the kidney might be associated with some occupational agents. Several substances, occupations, and industries have been associated with an increased risk of kidney cancer including cadmium, ${ }^{2}$ asbestos, ${ }^{3,4}$ tar and pitch products, ${ }^{5}$ petroleum related workers, ${ }^{5-8}$ coke oven workers, ${ }^{9}$ truck drivers, ${ }^{10}$ newspaper pressmen, ${ }^{11}$ printing industry, ${ }^{8}$ laundry and dry cleaning, ${ }^{72}{ }^{13}$ and metal manufacturing. ${ }^{8}$ A suggestion of an association was also reported for tanners ${ }^{14}$ and textile workers. ${ }^{15}$ At present, however, coke and cadmium are the only two carcinogens causally or potentially related to renal cancer. ${ }^{16}$ Lastly, an increased risk of renal cancer was also reported among white collar workers. ${ }^{817}$

We report here the results of a case-control study conducted in France from 1987 to 1991 on 196 cases of renal cell carcinoma.

\section{Materials and methods}

The design of the study has been reported previously. ${ }^{18}$ Data were collected in 10 hospitals and were obtained from 138 men and 58 women with a histologically proved renal cell carcinoma.

Each case was matched for sex, age at interview (within five years), hospital, and interviewer with two controls (one control with a malignant disease and one with a non-malignant disease) admitted to hospital for a nontobacco related disease. Patients with alcoholic cirrhosis or diabetes were not included. One hundred and fifty one cases were matched to two controls and the other 45 cases to one control only. This was due to difficulties in recruitment because of the matching and eligibility criteria. In all, 161 controls with cancer (107 men and 54 women) and 186 controls with non-malignant disease (128 men and 58 women) were included. Participation was almost complete, as only one case and two controls approached for interview refused to participate. Information was collected from the study participants during the course of their stay in hospital with a standardised questionnaire used by trained interviewers. The questionnaire included questions about the educational level, height, weight at two time points, smoking habits, consumption of beverages, and certain types of medication. A complete occupational history was recorded. Respondents were asked to indicate their occupational history (from the most recent to the first occupation) and the duration at each position (at least one year). Interviewers were aware of the case or control state, but the data were coded blindly with the International Standard Classification of Occupations. ${ }^{19}$

\section{ANALYTICAL METHODS}

Data were validated by the PIGAS system. ${ }^{20}$ Conditional logistic regression ${ }^{21}$ was used to estimate the odds ratio (OR) of renal cell cancer and the $95 \%$ confidence intervals (95\% CIs). Analyses were performed separately for men and women. The matched ORs are implicitly adjusted for the matching variables age, hospital, and interviewer. Moreover, adjustments for the educational 
Table 1 Adjusted matched ORs of renal cell carcinoma for major groups of occupations ${ }^{\star}$

\begin{tabular}{|c|c|c|c|c|c|c|}
\hline & \multicolumn{3}{|l|}{ Men } & \multicolumn{3}{|c|}{ Women } \\
\hline & $\begin{array}{l}\text { No of } \\
\text { cases }\end{array}$ & $\begin{array}{l}\text { No of } \\
\text { controls }\end{array}$ & $\begin{array}{l}\text { Matched ORt } \\
(95 \% \mathrm{CI})\end{array}$ & $\begin{array}{l}\text { No of } \\
\text { cases }\end{array}$ & $\begin{array}{l}\text { No of } \\
\text { controls }\end{array}$ & $\begin{array}{l}\text { Matched OR† } \\
(95 \% \text { CI })\end{array}$ \\
\hline Professional, technical, related & 43 & 58 & $1 \cdot 1(0 \cdot 6-2 \cdot 0)$ & 9 & 20 & $0.5(0 \cdot 2-1 \cdot 4)$ \\
\hline $\begin{array}{l}\text { workers }(011-199) \\
\text { Administrative and managerial } \\
\text { workers }(201-219)\end{array}$ & 19 & 14 & $2 \cdot 3(1 \cdot 0-5 \cdot 4)$ & 0 & 0 & - \\
\hline $\begin{array}{l}\text { workers }(201-219) \\
\text { Clerical and related workers } \\
(300-399)\end{array}$ & 24 & 39 & $1 \cdot 2(0 \cdot 7-2 \cdot 1)$ & 22 & 28 & $1.6(0.7-3.5)$ \\
\hline $\begin{array}{l}\text { Sales workers }(400-490) \\
\text { Service workers }(500-599) \\
\text { Agricultural, animal } \\
\text { husbandry, and forestry } \\
\text { workers, fishermen, and } \\
\text { hunters }(600-649)\end{array}$ & $\begin{array}{l}29 \\
12 \\
20\end{array}$ & $\begin{array}{l}32 \\
36 \\
37\end{array}$ & $\begin{array}{l}2 \cdot 1(1 \cdot 2-4 \cdot 0) \\
0 \cdot 4(0 \cdot 2-1 \cdot 0) \\
1 \cdot 2(0 \cdot 6-2 \cdot 3)\end{array}$ & $\begin{array}{l}8 \\
4 \\
4\end{array}$ & $\begin{array}{r}13 \\
27 \\
8\end{array}$ & $\begin{array}{l}1.4(0.5-3.7) \\
0.3(0.1-0.8) \\
1.5(0.4-6.3)\end{array}$ \\
\hline $\begin{array}{l}\text { Production and related } \\
\text { workers, transport equipment } \\
\text { operators, and labourers (700-999) }\end{array}$ & 52 & 110 & $0.8(0.5-1 \cdot 3)$ & 13 & 31 & $0.7(0.3-1 \cdot 7)$ \\
\hline
\end{tabular}

${ }^{\star}$ Groups classified according to the International Standard Classification of Occupations (ISCO, 1968).

tAdjusted for number of years at school $(\leqslant 4,5-7,8-10, \geqslant 11)$, smoking state (non-smokers, ever smokers), and Quetelet index before diagnosis $(\leqslant 20,21-23,24-26, \geqslant 27)$

level, cigarette smoking, and the Quetelet index before diagnosis were done. The occupations studied were similarly distributed between the two series of controls. The analyses were conducted in each control group for major groups of occupations. As similar results were obtained for both control groups in women and in men, only the matched analysis with the pooled control groups is given here. A result was considered nonsignificant (NS) when its associated $p$ value was above $0 \cdot 05$.

Table 2 Adjusted matched ORs for renal cell carcinoma for some occupations* in men

\begin{tabular}{|c|c|c|c|}
\hline & $\begin{array}{l}\text { No of } \\
\text { cases }\end{array}$ & $\begin{array}{l}\text { No of } \\
\text { controls }\end{array}$ & $\begin{array}{l}\text { Matched ORt } \\
(95 \% \text { CI })\end{array}$ \\
\hline $\begin{array}{l}\text { Architects, engineers, and related workers (021-039) } \\
\text { Life scientists, medical, dental, veterinary, and }\end{array}$ & $\begin{array}{r}22 \\
4\end{array}$ & $\begin{array}{l}24 \\
11\end{array}$ & $\begin{array}{l}1 \cdot 4(0 \cdot 7-2 \cdot 8) \\
0 \cdot 4(0 \cdot 1-1 \cdot 4)\end{array}$ \\
\hline $\begin{array}{l}\text { Teachers }(131-139) \\
\text { Managers }(210-219)\end{array}$ & $\begin{array}{r}6 \\
17\end{array}$ & $\begin{array}{r}9 \\
8\end{array}$ & $\begin{array}{l}1 \cdot 0(0 \cdot 3-3 \cdot 2) \\
3 \cdot 3(1 \cdot 2-8 \cdot 9)\end{array}$ \\
\hline $\begin{array}{l}\text { Cooks, waiters, bartenders, and related workers (531- } \\
\text { 532) }\end{array}$ & 2 & 13 & $0 \cdot 2(0 \cdot 0-1 \cdot 1)$ \\
\hline $\begin{array}{l}\text { Protective service workers }(580-589) \\
\text { Farmers, agricultural and animal husbandary workers } \\
(611-629)\end{array}$ & $\begin{array}{r}3 \\
18\end{array}$ & $\begin{array}{l}10 \\
36\end{array}$ & $\begin{array}{l}0.4(0 \cdot 1-1 \cdot 7) \\
1.0(0 \cdot 5-2 \cdot 0)\end{array}$ \\
\hline $\begin{array}{l}\text { Forestry workers, cabinet makers, and related } \\
\text { woodworkers }(631-632,811,812,819)\end{array}$ & 4 & 6 & $0 \cdot 7(0 \cdot 2-3 \cdot 2)$ \\
\hline $\begin{array}{l}\text { Texile workers and tailors (750-759, 791-799) } \\
\text { Blacksmiths, toolmakers, and machine tool operators }\end{array}$ & $\begin{array}{l}6 \\
7\end{array}$ & $\begin{array}{r}3 \\
12\end{array}$ & $\begin{array}{l}6 \cdot 2(1 \cdot 2-33 \cdot 7) \\
1 \cdot 5(0 \cdot 5-4 \cdot 5)\end{array}$ \\
\hline $\begin{array}{l}\text { Machinery fitters, machine assemblers, and precision } \\
\text { instrument makers }(841-849)\end{array}$ & 8 & 16 & 0.7 \\
\hline $\begin{array}{l}\text { Electrical fitters and related electrical and } \\
\text { electronics workers }(851-859)\end{array}$ & 4 & 10 & $0.8(0.2-2.5)$ \\
\hline $\begin{array}{l}\text { Plumbers, welders, sheet metal, and structural metal } \\
\text { preparers and erectors (871-874) }\end{array}$ & 2 & 7 & $0 \cdot 6(0 \cdot 1-3 \cdot 6)$ \\
\hline $\begin{array}{l}\text { Bricklayers, carpenters, and other construction } \\
\text { workers }(951-959)\end{array}$ & 8 & 21 & $0.9(0 \cdot 3-2 \cdot 1)$ \\
\hline port equipment operators $(981-989)$ & 4 & 14 & $0.5(0.2-1 \cdot 6)$ \\
\hline
\end{tabular}

${ }^{*}$ Groups classified according to the International Standard Classification of Occupations. ${ }^{18}$ tAdjusted for number of years at school $(\leqslant 4,5-7,8-10, \geqslant 11)$, smoking state (non-smokers, ever smokers) and Quetelet index before diagnosis $(\leqslant 20,21-23,24-26, \geqslant 27)$.

Table 3 Adjusted matched ORs for renal cell carcinoma for some occupations ${ }^{*}$ in women

\begin{tabular}{llcl}
\hline & $\begin{array}{l}\text { No of } \\
\text { cases }\end{array}$ & $\begin{array}{l}\text { No of } \\
\text { controls }\end{array}$ & $\begin{array}{l}\text { Matched ORt } \\
(95 \% \text { CI })\end{array}$ \\
\hline Teachers (131-139) & 6 & 6 & $1 \cdot 6(0 \cdot 4-6 \cdot 5)$ \\
Building caretakers, charworkers, cleaners, and & 2 & 10 & $0 \cdot 4(0 \cdot 1-2 \cdot 3)$ \\
related workers $551-552)$ & 4 & 8 & $1 \cdot 5(0 \cdot 4-6 \cdot 3)$ \\
Farmers, agricultural and animal husbandry workers & 4 & 14 & $0.9(0 \cdot 3-2 \cdot 6)$ \\
(611-629) & 7 & 14 & Textile workers and tailors $(750-759,791-799)$
\end{tabular}

${ }^{\star}$ Groups classified according to the International Standard Classification of Occupations. ${ }^{19}$ tAdjusted for number of years at school $(\leqslant 4,5-7,8-10, \geqslant 11)$, smoking state (non-smokers, tAdjusted for number of years at school $(\leqslant 4,5-7,8-10, \geqslant 11)$, smoking stat
ever smokers $)$ and Quetelet index before diagnosis $(\leqslant 20,21-23,24-26, \geqslant 27)$.

\section{Results}

For each occupation of interest, the baseline category was composed of patients who had never been engaged in that particular occupation. Table 1 shows the matched OR of renal cell carcinoma for major groups of occupations, adjusted for the educational level, exposure to cigarettes, and the Quetelet index. In men, a significant excess risk of renal cell cancer, or one of borderline significance, was found for sales workers $(\mathrm{OR}=2 \cdot 1,95 \% \mathrm{CI}$ $1 \cdot 2-4 \cdot 0$ ), and for administrative and managerial workers $(\mathrm{OR}=2 \cdot 3,95 \%$ CI $1 \cdot 0-5 \cdot 4)$. By contrast, the lower risk for service workers was of borderline significance $(\mathrm{OR}=0.4,95 \% \mathrm{CI}$ $0 \cdot 2-1 \cdot 0)$. None of the risks were significantly increased among women. A significant decreased risk was found for service workers $(\mathrm{OR}=0.3,95 \%$ CI $0 \cdot 1-0 \cdot 8)$. There was no evidence of an increase in risk with the duration of exposure for any major occupational group, neither in men nor in women.

A more detailed analysis was performed for occupations either including at least 10 cases or controls or both or previously reported to be associated with renal cancer in men (table 2 ) and in women (table 3 ). In men, a significant $3 \cdot 3$-fold risk (95\% CI $1 \cdot 2-8 \cdot 9)$ of renal cell carcinoma was found for managers. Because of the small number of men working in the textile industry, and of tailors and related workers, these two occupational groups were pooled, and a significantly increased risk was found $(\mathrm{OR}=6 \cdot 2,95 \% \mathrm{CI}$ $1 \cdot 2-33 \cdot 7)$. Moreover, evidence indicated an increase in risk with the duration of exposure: the risk for renal cell cancer was 1.7 (95\% CI $0 \cdot 1-21 \cdot 8$ ) after 10 years or less of exposure and $12.9(95 \%$ CI $1 \cdot 4-120 \cdot 1)$ after more than 10 years of exposure (trend test $p=0.02$ ). Risks associated with other occupational groups were mostly close to one and there was no evidence of an increase in risk with the duration of exposure. As the number of women involved in the study (58 cases and 112 controls) was rather small and because about $20 \%$ of women had no occupation, the analyses were restricted to fewer occupational groups than for men. None of the risks were significantly increased (table 3 ). 


\section{Discussion}

The associations between renal cell carcinoma and some occupations found in this study are consistent with those previously reported. In one study, ${ }^{17}$ there was a significantly increased risk for male white collar administrative workers. Our study also showed a significant twofold risk for this occupational group, and within this group a significant 3.3-fold risk for managers. In another study, ${ }^{8}$ the risk was also about twofold for white collar occupations considered as a whole. Likewise, in our study a significant twofold risk was found for male sales workers. This result is in agreement with that reported previously. ${ }^{17}$ The over-representation of non-manual workers among the cases reflects a higher educational level among cases than among controls in our study. Even after adjustment for the educational level, however, the risks of renal cancer were increased among white collar workers. As non-manual workers are less exposed to toxic agents than manual workers, and because the most consistently reported risk factors of renal cell cancer (smoking and obesity) were taken into account in the analyses, other lifestyle habits than those recorded in this study may account for the associations found here.

Male textile workers and tailors had a significant $6 \cdot 2$-fold excess risk of renal cell carcinoma. This result corroborates previous findings that showed a higher proportion of men who had worked with textiles among cases than among controls. ${ }^{15}$ Whereas the number of female textile workers was greater than that of male workers, the risk was not significantly different from unity in female workers. This result could be explained by the greater duration of exposure in male cases (26 years) than in male controls (18 years), whereas the duration of exposure was the same in female cases and in female controls (15 years). By contrast, a significant threefold risk of renal cell cancer was found for truck drivers in one study ${ }^{10}$ but not in ours. Similarly, a significant decreased risk was found for agricultural workers in two studies, ${ }^{8}$ ${ }^{17}$ but this result was not confirmed in another study, ${ }^{22}$ nor in ours.

The relative risks of renal cell carcinoma previously reported to be increased ${ }^{5-9} 12-14$ among certain other occupational groups (petroleum refining workers, printing, laundry workers, oven workers, and tanners) could not be estimated in this study because the number of cases and controls for each occupational category was too small. As only occupations were recorded in this study, it was not possible to evaluate the risks related to a specific exposure to substances such as asbestos, cadmium, coke, tar, or pitch. As the reference category used to study a given occupation included people potentially exposed to other toxic substances it is likely that some negative results may reflect an underestimation of the risks.

Despite these reservations, and the negative results of several studies investigating relations between renal cell cancer and occupations, ${ }^{22-25}$ the present study provides a certain amount of evidence that some occupations, as well as smoking and obesity, could be related to this cancer.

We thank Ms Lorna Saint-Ange for editing the manuscript We are grateful to the following physicians for their contributio to data: Dr G Akoun, Dr B Amor, Dr JP Armand, Dr L Auquier, Dr P Banzet, Dr J Benoit, Dr $H$ Bensadoun, Dr $M$ Camey, Dr R Caquet, Dr P Carde, Dr G Cathelineau, Dr J Civatte, Dr B Court, Dr GA Cremer, Dr J Denis, Dr JP Droz Dr L Dubertret, Dr JP Etienne, Dr D Fritel, Dr B Genevray, Dr J Guedon, Dr J Guerre, Dr H Hamard, Dr M Hayat, Dr M Huguier, Dr A Jardin, Dr G Kaplan, Dr J Lapresle, Dr P Huguier, Dr A Jardin, Dr G Kaplan, Dr J Lapresle, Dr P Laudenbach, Dr D Lebuisson, Dr A Le Duc, Dr C Leleu, Dr G
Lormeau, Dr J Marsac, Dr P Massias, Dr F Mazas, Dr CJ Lormeau, Dr J Marsac, Dr P Massias, Dr F Mazas, Dr CJ Dr J Rouffy, Dr G Schaison, Dr A Steg, Dr JD Sraer, Dr J Dr J Rouffy, Dr G Schaison, Dr A Steg, Dr JD Sraer, Dr J
Taillandier, Dr P Testas, Dr P Teyssier, Dr J Verges, Dr J Witvoet.

This study was supported by grants from the Caiss Nationale d'Assurance Maladie des Travailleurs Salariés and the Institut National de la Santé et de la Recherche Médicale.

1 Devesa SS, Silverman DT, McLaughlin JK, Brown CC Connelly RR, Fraumeni JF. Comparison of the descriptive epidemiology of urinary tract cancers. Cancer Causes Control 1990;1:133-41.

2 Kolonel LN. Association of cadmium with renal cancer. Cancer 1976;37:1782-7.

3 Selikoff IJ, Hammond EC, Seidman M. Mortality experience of insulation workers in the United States and Canada, 1943-1976. Ann NY Acad Sci 1979;330 91-116.

4 Maclure $M$. Asbestos and renal adenocarcinoma: a casecontrol study. Environ Res 1987;42:353-61.

5 McLaughlin JK, Mandel JS, Blot WJ, Schuman LM, Meh ES, Fraumeni JF. A population-based case-control study of renal cell carcinoma. $\mathcal{F}$ Natl Cancer Inst 1984;72: of renal

6 McLaughlin JK, Blot WJ, Mehl ES, Stewart PA, Venable FS, Fraumeni JF. Petroleum-related employment and FS, Fraumeni JF. Petroleum-related employ

7 Asal NR, Geyer JR, Risser DR, Lee ET, Kadamani S, Cherng $\mathbf{N}$. Risk factors in renal cell carcinoma. II. Medical history, occupation, multivariate analysis, and conclusions. Cancer Detect Prev 1988;13:263-79.

8 Partanen T, Heikkilä P, Hernberg S, Kauppinen T, Moneta G, Ojajärvi A. Renal cell cancer and occupation exposure to chemical agents. Scand 7 Work Environ Health 1991;17:231-9.

9 Redmond CK, Ciocco A, Lloyd W, Ruch HW. Long-term mortality study of steelworkers. VI. Mortality from malignant neoplasms among coke oven workers. $\mathcal{F}$ Occup Med 1972;14:621-9.

10 Brownson RC. A case-control study of renal cell carcinoma in relation to occupation, smoking and alcoho consumption. Arch Environ Health 1988;43:238-41.

11 Paganini-Hill A, Glazer E, Henderson BE, Ross RK Cause-specific mortality among newspaper web pressmen. F Occup Med 1980;22:542-4.

12 Katz RM, Jowett D. Female laundry and dry cleaning workers in Wisconsin: a mortality analysis. Am $¥$ Public Health 1981;71:305-7.

13 Duh R, Asal NR. Mortality among laundry and dry cleaning workers in Oklahoma. Am $\mathscr{f}$ Public Health 1984;74: 1278-80.

14 Malker HSR, Malker BK, McLaughlin JK, Blot WJ. Kidney cancer among leather workers. Lancet 1984;i:56.

15 Wynder EL, Mabuchi K, Whitmore WF. Epidemiology of adenocarcinoma of kidney. $\mathcal{F}$ Natl Cancer Inst 1974;53: 1619-34.

16 Bureau International du Travail. La prévention du cancer professionnel. Geneva: BIT, 1989.

17 McLaughlin JK, Malker HSR, Stone BJ, Weiner JA, Malker BK, Ericsson JLE, et al. Occupation risks for renal cancer in Sweden. Br f Ind Med 1987;44:119-23.

18 Benhamou S, Lenfant MH, Ory-Paoletti C, Flamant R. Risk factors for renal cell carcinoma in a French casecontrol study. Int $\mathcal{f}$ Cancer 1993;55:32-6.

19 International Labour Office. International Standard Classification of Occupations. Geneva:ILO, 1968.

20 Wartelle M, Kramar A, Jan P, et al. PIGAS: an interactive statistical database management system. In: Proceedings of the second international workshop on statistical database of the second international workshop on statistical data
management. Los Altos: California 1983:124-32.

21 Breslow NE, Day NE. Statistical methods in cancer research. Vol. 1. The analysis of case-control studies. Lyon International Agency for Research on Cancer 1982:32.

22 Talamini R, Baron AE, Barra S, et al. A case-control study of risk factor for renal cell cancer in northern Italy. Cancer Causes Control 1990;1:125-31.

23 Armstrong B, Garrod A, Doll R. A retrospective study of renal cancer with special reference to coffee and anima protein consumption. $B r \mathcal{F}$ Cancer 1976;33:127-36.

24 Goodman MT, Morgenstern H, Wynder EL. A case-control study of factors affecting the developpment of renal cell cancer. Am f Epidemiol 1986;124:926-41.

25 McLaughlin JK, Gao Y, Gao R, Zheng W, Blot WJ. Risk factors for renal-cell cancer in Shanghai, China. Int $\mathcal{F}$ Cancer 1992;52:562-5. 